\title{
Pengaruh Penggunakan Pembelajaran Informal Kooperatif Berbantuan Aplikasi Schoology terhadap Minat Siswa dalam Belajar
}

\author{
Rakhmatul Ummah ${ }^{1}$, Rizalul Fiqry ${ }^{2}$ \\ ${ }^{1,2}$ STKIP Taman Siswa Bima, Nusa Tenggara Barat, Indonesia \\ E-mail: amumgi@gmail.com
}

\section{Article Info \\ Article History \\ Received: 2021-10-09 \\ Revised: 2021-11-02 \\ Published: 2021-11-19}

Keywords:

Learning;

Informal;

Cooperative;

Schoology;
Interest to learn.

\begin{abstract}
The increase in the number of positive cases in Indonesia due to COVID-19 has made the Ministry of Education and Culture (Kemendikbud) recommend a way to reduce the spread of the virus by conducting online learning, where learning activities that are usually carried out face-to-face are carried out by distance learning. Educators believe that online has many opportunities for conducive learning, and an environment that is relevant to the characteristics of students, this study explores the effect of cooperative learning on student learning outcomes in terms of learning interest. The cooperative learning model used is Think Write Pair Share (TWPS) which is integrated into the learning management system (LMS) in the form of a Schoology application to measure students' interest in learning Physics, this research is an experimental study using a pre-test post-test design model. control group design. The research subjects consisted of two groups, namely the experimental group and the control group. All groups were given a pre-test (an instrument to measure learning outcomes) and a learning interest questionnaire using the ARCS model (attention, relevance, confidence, and satisfaction). all groups were given a posttest and a learning interest questionnaire. The last stage is a data processing and data analysis using ANCOVA, the result is that TPS cooperative learning assisted by Schoology can increase students' interest in learning with a significance level of 0.005 .
\end{abstract}

\begin{tabular}{l}
\hline Artikel Info \\
\hline Sejarah Artikel \\
Diterima: $2021-10-09$ \\
Direvisi: 2021-11-02 \\
Dipublikasi: 2021-11-19
\end{tabular}

Kata kunci: Pembelajaran; Informal; Kooperatif; Schoology; Minat Belajar.

\begin{abstract}
Abstrak
Peningkatan jumlah kasus positif di indonesia akibat covid 19 membuat Kementerian Pendidikan dan Kebudayaa (Kemendikbud) merekomendasikan cara untuk menurunkan penyebaran virus dengan melakukan pembelajaran secara online, dimana aktivitas pembelajaran yang biasanya dilakukan secara tatap muka dilakukan dengan pembelajaran jarak jauh. Pendidik percaya bahwa pembelajaran online memiliki banyak kesempatan dalam memberikan pembelajaran yang kondusif, dan lingkungan yang relevan dengan karakteristik peserta didik, penelitian ini mengeksplorasi pengaruh pembelajaran kooperatif terhadap hasil belajar peserta didik ditinjau dari minat belajar. Model pembelajaran kooperatif yang digunakan adalah Think Write Pair Share (TWPS) yang diintegrasikan ke dalam Learning management system (LMS) yang berupa aplikasi Schoology untuk mengukur minat siswa dalam belajar Fisika, penelitian ini merupakan penelitian eksperimen dengan menggunakan model desain pre-test post-test control group design. Subjek penelitian terdiri dari dua kelompok yaitu kelompok eksperimen dan kelompok kontrol. Semua kelompok diberikan pretest (instrumen untuk mengukur hasil belajar) dan angket minat belajar menggunakan model ARCS (attention, relevance, confidence, and satisfaction). semua kelompok diberikan posttest dan angket minat belajar. Tahap terakhir adalah pengolahan data dan analisis data menggunakan ANCOVA, hasilnya pembelajaran kooperatif TPS berbantuan Schoology dapat meningkatkan minat belajar siswa dengan taraf signifikansi 0,005 .
\end{abstract}

\section{PENDAHULUAN}

Wabah virus corona (covid-19) yang melanda telah memberikan tantangan tersendiri bagi lembaga pendidikan. Kondisi ini mengharuskan siswa dan tenaga pendidik untuk tetap stay at home, bekerja, belajar dan melakukan aktivitas apapun di rumah (Jamaluddin, D. R., \& Paujiah, 2020). Peningkatan jumlah kasus positif di indonesia membuat Kementerian Pendidikan dan
Kebudayaan (Kemendikbud) merekomendasikan cara untuk menurunkan penyebaran virus dengan melakukan pembelajaran secara online (Arifa, F. 2020). Hal ini secara tidak langsung mempercepat penerapan pendidikan 4.0 dan tuntutan kurikulum yang mengintegrasikan penggunaan TIK pada semua mata pelajaran untuk menciptakan pembelajaran yang inovatif dan kolaboratif, dimana keunggulan yang 
ditawarkan tidak hanya terletak pada faktor kecepatan dan kemudahan mendapatkan informasi atau sumber materi, namun beberapa fasilitas multimedia yang terdapat didalamnya dapat membuat proses pembelajaran menjadi lebih seru dan interaktif (Sulisworo, D., Ummah, R., Nursholih, M., \& Raharjo, W. 2020). Salah satunya dengan menggunakan Learning Management System (LMS) dengan menggunakan pembelajaraan kooperatif yang dapat membangun semangat dan minat belajar siswa. Model pembelajaran kooperatif yang digunakan adalah Think Write Pair Share (TWPS) yang diintegrasikan kedalam Learning management system (LMS). LMS yang digunakan dalam penelitian ini adalah Schoology.

\section{Think Write Paire Share}

Model pembelajaran Think Write Pair Share merupakan penggabungan Think Pair Share (TPS) dengan Think Talk Write (TTW) (Siregar, Y. I., \& Susito, H. 2017). Model pembelajaran TTW yang dibangun melalui proses berpikir (Think), berbicara (Talk), dan menulis (Write) (Suparya, I. K. 2019). TTW memiliki tahapan pembelajaran diawali dari siswa berpikir untuk memproses informasi dalam dirinya melalui proses membaca. Dari proses tersebut siswa mengkomunikasikan ide/gagasan dengan cara berbicara dalam kelompok. Pada proses ini siswa menyalurkan ide satu sama lain. Proses terakhir dalam model ini ialah menulis guna menyimpulkan hasil diskusi. Selain itu, siswa juga dapat memuculkan ide-ide baru dari hasil diskusi kelompok lain (Septiani, A., Wahyudi, W., \& Indarini, E. 2018); (Nadhiroh, H., Jamiah, Y., \& Yani, A. 2015); (Wirawan.,K,.2017).

Sedangkan model pembelajaran TPS, siswa bekerja secara berpasangan untuk menyelesaikan dan memecahkan masalah dengan suasana diskusi yang berbeda. Tahapan model TPS dimulai dengan memahami permasalahan secara individu. Pada proses memahami, siswa diberikan waktu untuk berpikir. Dari hasil pengerjaan secara individu, siswa dikelompokkan dengan pasangannya untuk berdiskusi tentang pekerjaannya masing-masing. Saat berdiskusi kelompok berpasangan, siswa menentukkan jawaban bersama dalam menyelesaikan masalah. Pada proses penutup dilakukan sharing bertujuan untuk membagikan ide dari kelompok berpasangan kepada seluruh kelompok lainnya (Ilham, I., \& Budhi, W. 2019); (Kusumaningrum, R. 2015); (Nadhiroh, H., Jamiah, Y., \& Yani, A. 2015); (Natalliasari, I.
2013); (Mawatiningsih, E., \& Yohana, W. 2019); (Suhartini, S. 2015).

Model pembelajaran TWPS yang telah dimodifikasi sesuai Kurikulum 2013 memiliki sintaks yaitu: Tahap think (mengamati, menanya dan mengumpulkan data), siswa dimotivasi untuk bertanya dan memikirkan jawaban dari pertanyaan. Tahap pair (mengasosiasikan), siswa mendiskusikan jawaban yang diperolehnya pada tahap think dengan pasangannya sehingga diperoleh jawaban terbaik. Tahap share (mengkomunikasikan), setiap kelompok mempresentasikan hasil terbaik dari tahap pair di depan kelas. Tahap write siswa menuliskan hasil pembelajaran kedalam jurnal belajar yang dibuat oleh setiap siswa, dengan menggunakan bahasannya sendiri sebagai bentuk pemahaman terhadap konsep yang dipelajari. Pembelajaran ini dapat meningkatkan keterlibatan semua siswa dalam kegiatan belajar dan juga aktivitas berpikir siswa (Siregar, Y. I., \& Susito, H. 2017).

\section{Learning Management System (LMS)}

Learning Management System (LMS) merupakan teknologi berbasis web yang menyediakan menu atau fitur untuk pembelajaran yang baik dalam mengelola dan menyampaikan materi ajar, memantau aktivitas siswa dalam pembelajaran, dan mengevaluasi pembelajaran siswa secara online (B. Lochner, 2015). Dapat dikatakan bahwa LMS memiliki skala yang lebih luas dibandingkan pembelajaran berbasis web terutama karena menu yang tersedia lengkap dan canggih (M. Henderson, N. Selwyn, R. Aston. 2017). Fitur-fitur yang tersedia di LMS memberikan potensi untuk meningkatkan kualitas pembelajaran yang searah dengan tujuan kurikulum. Fasilitas yang tersedia di LMS juga memungkinkan guru untuk berkomunikasi dan menyimpan informasi (bahan ajar, tugas siswa, kuis) yang dapat diakses kembali ke kebutuhan pembelajaran (B. Lochner, 2016). Di sisi lain, siswa memiliki akses sehingga dapat mengontrol dirinya sendiri terhadap sumber belajar dan kegiatan belajar yang ada tanpa dibatasi oleh ruang dan waktu. Siswa memiliki fleksibilitas dalam belajar ( C. Cavanaugh, J. Mayberry, 2016). Untuk mendukung kehadiran siswa dalam pembelajaran online, LMS juga memiliki fitur yang memungkinkan guru memberikan umpan balik, komentar interaktif dengan siswa baik secara sinkron (video, chat) maupun asinkron (forum, email, pesan) (S. J. Smith, W. Stahl, W 2016); 
(Sulisworo, D., Ummah, R., Nursholih, M., \& Raharjo, W. 2020)..

LMS yang digunakan dalam penelitian ini adalah Schoology, Schoology merupakan website yang memadukan e-learning dan jejaring sosial, memiliki konsep yang sama seperti Moodle, namun dalam hal e-learning Schoology mempunyai banyak kelebihan, dan menguntungkan dibandingkan menggunakan Moodle dikarenakan tidak memerlukan hosting dan pengelolaan. Schoology lebih user friendly. Tentu fiturnya tidak selengkap Moodle, namun untuk pembelajaran e-learning disekolah sudah sangat memadai (Slameto, 2010); (Sukanti, 2011). Kelebihan Schoology adalah tersedianya fasilitas attandance yang digunakan untuk mengecek kehadiran siswa, dan juga fasilitas analicy untuk melihat aktivitas siswa pada setiap course, assignment, discussion, dan aktivitas lain yang disiapkan untuk siswa (Ummah, R., \& Sulisworo, D. 2018).

\section{Minat Belajar Siswa}

Rasa ketertarikan terhadap sesuatu tidaklah dibawa sejak lahir, melainkan di peroleh kemudian dari berbagai macam proses, rasa ketertarikan umumnya dikenal sebagai minat. Dalam dunia pendidikan mengembangkan minat pada dasarnya adalah membantu siswa melihat bagaimana hubungan antara materi yang dipelajari dengan dirinya sendiri sebagai individu. Bila siswa melihat hasil dari pengalaman belajarnya akan membawa kemajuan pada dirinya, kemungkinan besar ia akan berminat untuk mempelajarinya (Lestari, I. 2016). Minat berhubungan dengan perhatian, seseorang yang memiliki minat pada mata pelajaran tertentu lebih cenderung memperhatikan mata pelajaran tersebut (Widodo. S.A, Pratiwi. W. 2012).

Minat belajar siswa akan timbul ketika siswa memiliki perasaan senang dan ketertarikan terhadap materi pelajaran. Adanya ketertarikan terhadap materi yang diberikan menjadikan siswa memiliki intensitas belajar yang tinggi sehingga memperoleh hasil belajar yang baik, dapat di katakan bahwa ada hubungan yang erat antara minat belajar dengan hasil belajar siswa (Aminoto, Panthoni. 2014).

\section{METODE PENELITIAN}

Penelitian ini merupakan penelitian eksperimen semu, model desain penelitian ini controled group pre test post test design yaitu rancangan secara acak dengan tes awal dan tes akhir dengan kelompok kontrol, kelas eksperimen diberi perlakuan sedangkan kelas kontrol tidak. Penelitian ini bertujuan untuk mengetahui pengaruh pembelajaran kooperatif informal Think Write Pair and Share (TWPS) berbantuan aplikasi Schoology terhadap minat belajar siswa siswa SMAN 1 SAPE, melalui penelitian ini, peneliti ingin mengetahui bahwa penggunaan model pembelajaran informatif Think Pair and Share berbantuan aplikasi Schoology dapat meningkatkan minat belajar siswa dalam pembelajaran fisika pada materi Elastisitas.

Kelompok eksperimen dan kelompok kontrol akan diberikan instrumen untuk mengukur hasil belajar (berupa soal) dan angket minat belajar model (ARCS), kemudian kelompok eksperimen akan diberikan pengajaran dengan menggunakan model pembelajaran kooperatif Think Write Paire Share berbantuan LMS (Schoology) selama waktu yang ditentukan, sedangkan kelompok kontrol akan diberikan pembelajaran secara konvensional. Setelah semua data didapatkan maka hasil akhir dari data yang didapat akan diolah menggunakan ANCOVA. Kemudian data penelitian yang didapat dibandingkan, kemudian menarik kesimpulan, dan memberikan saran.

\section{HASIL DAN PEMBAHASAN}

A. Analysis Demografis

Penelitian ini dilakukan dengan menggunakan dua kelas sebagai sampel penelitian, yaitu kelas kontrol dan kelas eksperimen. Setiap kelas terdiri dari 29 siswa, persentase siswa laki-laki yang diteliti $11 \%$ dan siswa perempuan 89\%, perhitungan ini diperoleh dari jumlah siswa laki-laki sebanyak 9 orang dan perempuan 49 orang. Jumlah siswa lakilaki pada kelas eksperimen adalah 5 orang, dan jumlah siswa laki-laki pada kelas kontrol adalah 4 orang, sedangkan jumlah siswa perempuan pada kelas eksperimen adalah 24 dan jumlah siswa perempuan pada kelas kontrol adalah 25 siswa.

\section{B. Minat Siswa}

Data minat belajar di peroleh dari data angket minat belajar ARCS yang di berikan kepada siswa setelah di berikan treatment, yang di ketahui bahwa nilai tertinggi 175, nilai terendah 103, mean 123,01, median 123, dan simpangan bakunya 9,468. Distribusi frekuensi minat belajar secara lengkap di sajikan dan di perjelas pada gambar berikut: 


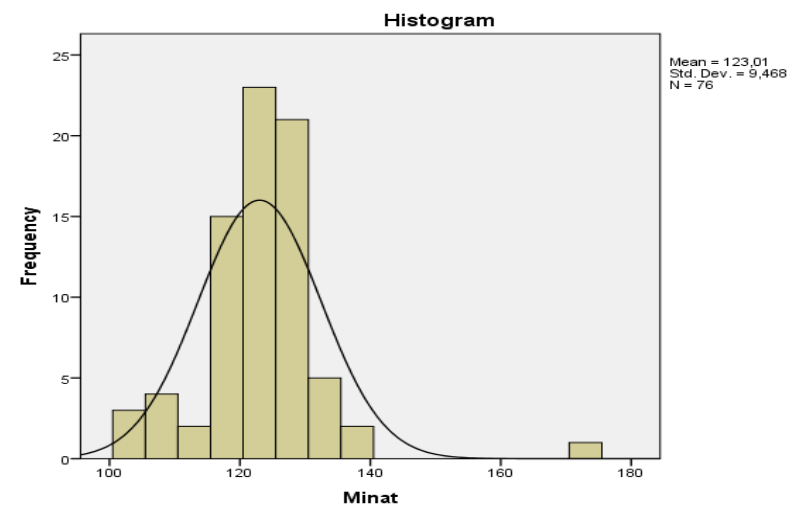

Gambar 1. Histogram Gabungan Minat masingmasing kelas

Untuk skor kelas kontrol memiliki nilai tertinggi 131, nilai terendah 103, mean 125,34 , median 126, dan simpangan bakunya 10,82. Sedangkan skor kelas eksperimen nilai tertinggi 175, nilai terendah 103, mean 120,68 , median 122,5 dan simpangan bakunya 7,319 . Histogram untuk masing-masing kelas perlakuan disajikan pada gambar 2 dan gambar 3 .

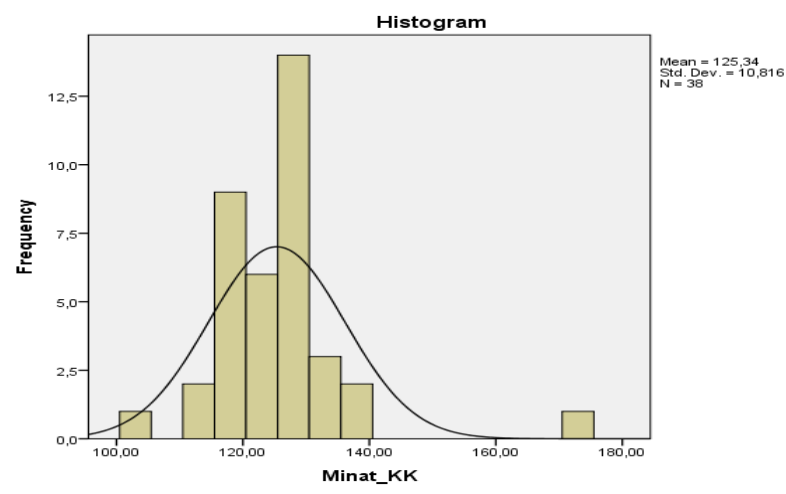

Gambar 2. Histogram Minat Kelas Kontrol

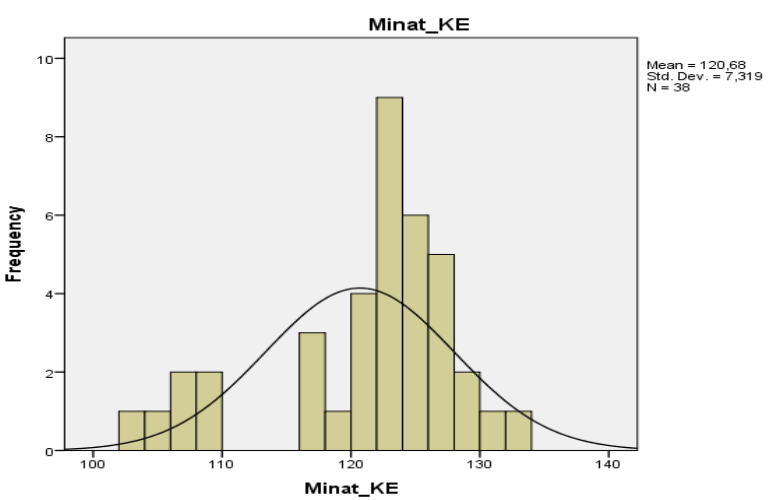

Gambar 3. Histogram Minat Kelas Eksperimen

Dari data di atas dapat dilihat bahwa data yang di peroleh antara nilai angket kelas kontrol dan angket kelas eksperimen memiliki nilai yang berbeda, berarti bisa dikatakan bahwa minat belajar yang dimiliki oleh kelas eksperimen lebih tinggi dibandingkan dengan minat belajar yang dimiliki oleh kelas kontrol , dapat dilihat dari nilai terendah dan nilai tertinggi siswa, yaitu nilai terendah untuk masing-masing kelas sama yaitu 103, sedangkan untuk nilai tertinggi dari masingmasing kelas terpaut jauh, kelas kontrol dengan nilai tertinggi 140 dan nilai tertinggi kelas eksperimen yaitu 175, persentasi perolehan nilai nilai angket yang didapat untuk kelas eksperimen adalah sebesar $55 \%$ sedangkan persentasi nilai angket yang didapat untuk kelas kontrol adalah $45 \%$.

Perbedaan persentasi hasil dari angket minat yang didapat ini kemungkinan ditimbulkan oleh karena adanya perbedaan treatment yang diberikan kepada tiap kelas, kelas kontrol diberikan treatment dengan pembelajaran konvensional dengan metode ceramah sedangkan kelas eksperimen diberikan treatment dengan menggunakan pembelajaran informal kooperatif tipe think pair and share (TPS) berbantuan aplikasi Schoology, sehingga bisa disimpulkan jika di lihat dari segi persentasi yang didapatkan dari hasil angket, bahwa minat belajar siswa kelas eksperimen yang diberikan pembelajaran informal kooperatif TPS lebih besar dari pada minat belajar siswa yang diberikan metode konvensional.

Untuk lebih mengetahui dan mengetahui lebih jelas apakah ada pengaruh dari adanya pemberian treatment kepada masing-masing hasil yang diperoleh dengan melakukan perhitungan ANCOVA menggunakan Uji t, Ada perbedaan minat belajar siswa antara model pembelajaran informal kooperatif tipe think Write pair and share berbantuan aplikasi Schoology untuk kelas eksperimen (KE) dan model pembelajaran ceramah untuk kelas kontrol (KK). Hasil perhitungan yang diperoleh menunjukkan seperti yang ditunjukkan pada tabel berikut:

Tabel 1. Hasil uji- $t$ untuk Minat Belajar Siswa

\begin{tabular}{lrrrr}
\hline Variabel & Mean & Sig & thit & ttabel, 5\% \\
\hline Miat Belajar (KK) & 117,21 & & & \\
$\begin{array}{l}\text { Minat Belajar } \\
\text { (KE) }\end{array}$ & 125,34 & 0,029 & 3,280 & 2,024 \\
\end{tabular}

Dari data di atas dapat dilihat bahwa hasil yang diperoleh dari perhitungan uji-t untuk mengetahui adakah perbedaan yang didapakan dari minat belajar antara kelas eksperimen yang diberikan metode pembelajaran informal kooperatif berbantuan aplikasi 
Schoology dan kelas kontrol yang diberikan metode pembelajaran ceramah, dapat dilihat bahwa hasil hitung thit yang di dapat adalah 3,280 berarti lebih besar dari pada taraf signifikansi 0,05 (t hitung $=3,280$, sig $>0,05$ ) ) serta $t$ siginifikansi yang diperoleh lebih besar dari pada taraf signifikansi $0,005 \quad((\mathrm{p}>$ $0,05) ;(0,029>0,05))$. Dari perhitungan yang diperoleh dapat dilihat kelas yang memiliki nilai rata-rata mean tinggi, dari data yang diperoleh kelas eksperimen memiliki minat belajar yang lebih tinggi yaitu 125,34 sedangkan kelas kontrol memperoleh minat belajar sebesar 117,21, bisa dilihat juga bahwa nilai $t_{\text {hit }}$ lebih besar dari pada $t_{\text {tab }}\left(t_{\text {hit }}\right.$ > $t_{\mathrm{tab}}$ ) yaitu 3,280 > 2,024 dari semua data yang diperoleh dapat disimpulkan bahwa terdapat perbedaaan antara minat belajar yang diberikan antara kelas eksperimen dan kelas kontrol, dimana kelas eksperimen memiliki perolehan nilai minat belajar yang lebih tinggi jika dibandingkan dengan kelas kontrol.

\section{SIMPULAN DAN SARAN}

\section{A. Simpulan}

Hasil analisis menunjukkan bahwa terdapat pengaruh penggunaan pembelajaran kooperatif Think Write Pair Share berbantuan LMS terhadap minat siswa dalam belajar Fisiska. Schoology merupakan LMS yang mudah digunakan karena mudah digunakan ditambah dengan fasilitas penunjang yang terdapat di dalamnya, dapat diakses oleh banyak kalangan, seperti guru, murid maupun orang tua murid, dan yang paling penting Schoology dapat diakses secara gratis, apalagi jika digabungkan menggunakan model. pembelajaran kooperatif seperti Think Write Pair Share.

\section{B. Saran}

Adapun saran yang dapat disampaikan berdasarkan hasil penelitian tindakan ini, yaitu Penggunaan pembelajaran kooperatif think pair and share berbantuan aplikasi Schoology perlu diterapkan dalam proses pembelajaran agar dapat menumbuhkan minat belajar siswa dengan baik sehingga mampu meningkatkan hasil belajar.

\section{Ucapan Terimakasih}

Terimakasih Kementerian Riset, Teknologi, dan Pendidikan Tinggi Republik Indonesia dengan Skema Penelitian Dosen Pemula, Tahun 2021 yang telah mendanai penelitian ini.

\section{DAFTAR RUJUKAN}

Aminoto, Panthoni. (2014). Penerapan Media Elearning Berbasis Schoology untuk Meningkatkan Aktivitas dan Hasil Belajar Materi Usaha dan Energi di Kelas XI SMA N 10 Kota Jambi. Jurnal Pendidikan Fisika, Universitas Jambi.

Arifa, F. (2020). Tantangan Pelaksanaan Kebijakan Belajar dari Rumah dalam Masa Darurat covid-19. Jakarta: Kajian Singkat Terhadap Isu Aktual dan Strategis.

B. Lochner, R. M. Conrad, E. Graham, (2016). E. The Relationship between Teacher Characteristics and Their Concerns in Adopting Learning Management Systems, In EdMedia+ Innovate Learning (pp. 553-562), Association for the Advancement of Computing in Education (AACE),

B. Lochner, R. M. Conrad, E. Graham. (2015). Secondary teachers' concerns in adopting learning management systems: A US perspective, TechTrends, Vol. 59, No. 5, 6270 ,

C. Cavanaugh, J. Mayberry, (2016) J. Hargis. Participation in the virtual environment of blended college courses: An activity study of student performance, International Journal on E Learning, Vol. 15, No. 4, 423-432,

Ilham, I., \& Budhi, W. (2019). Pengaruh Model Pembelajaran Kooperatif Tipe Think Pair Share Terhadap Prestasi Belajar Fisika Pokok Bahasan Getaran Dan Gelombang. Compton: Jurnal Ilmiah Pendidikan Fisika, $5(1)$.

Jamaluddin, D. R., \& Paujiah. (2020). Pembelajaran Daring Masa Pandemik Covid 19 Pda Calon Guru: Hambatan, Solusi dan Proyeksi. Karya Tulis Ilmiah UIN Sunan Gunung Djjati Badung, 1-10.

Kusumaningrum, R., Budiyono, B., \& Subanti, S. (2015). Eksperimentasi Model Pembelajaran Kooperatif Tipe Two Stay Two Stray (TSTS), Numbered Heads Together (NHT), dan Think Pair Share (TPS) Pada Materi Lingkaran Ditinjau Dari Kreativitas Belajar Matematika Siswa SMP Negeri di Kabupaten Sukoharjo. Jurnal Pembelajaran Matematika, 3(7). 
Lestari, I. (2016). Pengaruh Waktu Belajar dan Minat Belajar Terhadap Hasil Belajar Matematika. E-Jurnal Formatif. Vol. 3 (2).

M. Henderson, N. Selwyn, R. Aston. (2017). What works and why? Student perceptions of 'useful' digital technology in university teaching and learning, Studies in Higher Education, Vol. 42, No. 8, 1567-1579.

Mawatiningsih, E., \& Yohana, W. (2019). Efektifitas model Think Talk Write \& Think Pair Share Terhadap Peningkatan Kemampuan Komunikasi Matematis Siswa Kelas 4 SD. Satya Widya, Vol (37)1.

Nadhiroh, H., Jamiah, Y., \& Yani, A. (2015). Model Pembelajaran TTW dan TPS Terhadap Kemampuan Komunikasi Matematis Siswa Dalam Materi Bangun Datar. Jurnal Pendidikan dan Pembelajaran, 4(9).

Natalliasari, I. (2013). Penggunaan Model Pembelajaran Kooperatif Tipe Think Pair Share (TPS) Untuk Meningkatkan Kemampuan Penalaran Dan Pemecahan Masalah Matematis Siswa MTs (Doctoral dissertation, Universitas Terbuka).

S. J. Smith, W. Stahl, W (2016). Determining the Accessibility of K-12 Digital Materials: Tools for Educators, Journal of Special Education Leadership, 29(2), 89-100.

Septiani, A., Wahyudi, W., \& Indarini, E. (2018). Penerapan Metode Think Talk Write Untuk Meningkatkan Kemampuan Komunikasi Dan Hasil Belajar Tema Daerah Tempat Tinggalku Siswa Kelas 4 Sdn Tegalrejo 01. KALAM CENDEKIA PGSD KEBUMEN, 6(3.1).

Siregar, Y. I., \& Susito, H. (2017). Pengaruh Think Pair Share Write Berbasis HYbrid Learning Terhadap Keterampilan Metakognitif, Berpikir Kreatif, dan Hasil Belajar Kognitif Siswa SMAN 3 Malang. Jurnal Pendidikan Biologi Indonesia, Vol (3) 2.
Slameto. (2010). Belajar dan Faktor- Faktor yang Mempengaruhinya. Jakarta: Rineka Cipta.

Suhartini, S. (2015). Peningkatan Keterampilan Menulis Naskah Drama Satu Babak Menggunakan Model Think-Pair-Share Berbantuan Alat Peraga Gambar Berseri. Satya Widya, 31(2), 83-89.

Sukanti. (2011). Penilaian Efektif Dalam Pembelajaran Akuntansi. Jurnal Pendidikan Akuntansi Indonesia, Vol. IX No.1, 74-82.

Sulisworo, D., Ummah, R., Nursholih, M., \& Raharjo, W. (2020). The Analysis of The Critical Thingking Skills Between Blended Learning Implementation: Google Classroom and Schoology. Universal Journal of Educational Reseach 8(3)B, 33-40.

Suparya, I. K. (2019). Pengaruh Model Pembelajaran Kooperatif Tipe Think Talk Write (TTW) Terhadap Hasil Belajar Dan Kemampuan Berpikir Kritis Pada Pembelajaran IPA di Sekolah Dasar. Jurnal Widyacarya, 2(2), 19-24.

Ummah, R., \& Sulisworo, D. (2018). Pengaruh Pembelajaran Kooperatif Informal Think Pair Share Berbantuan Schoology Terhadap Hasil Belajar. Seminar Nasional Edusaintek FMIPA UNIMUS, 340-344.

Widodo. S.A, Pratiwi. W. (2012). Hubungan Antara Minat Belajar Dan Kemampuan Berpraktikum Dengan Hasil Belajar Fisika Pada Kompetensi DAsar Fluida Statis Siswa Kelas XI IPA SMA Negeri 5 Metro Lampung TAhun Pelajaran 2010/2011. Prosiding Seminar Nasional Penelitian Pendidikan dan Penerapan MIPA .

Wirawan.,K,.2017). Model Pembelajaran Kooperatif Think Talk Write (Cooperative TTW Learning Model). Jakarta: auniversitas Pendidikan Ganesha Fakultas MIPA Jurusan Pendidikan Fisika. 